\title{
Can Corruption Erode Confidence in Political Institutions Among European Countries? Comparing the Effects of Different Measures of Perceived Corruption
}

\section{Alessandro Pellegata \& Vincenzo Memoli}

\section{Social Indicators Research}

An International and Interdisciplinary Journal for Quality-of-Life Measurement

ISSN 0303-8300

Soc Indic Res

DOI 10.1007/s11205-015-1036-0

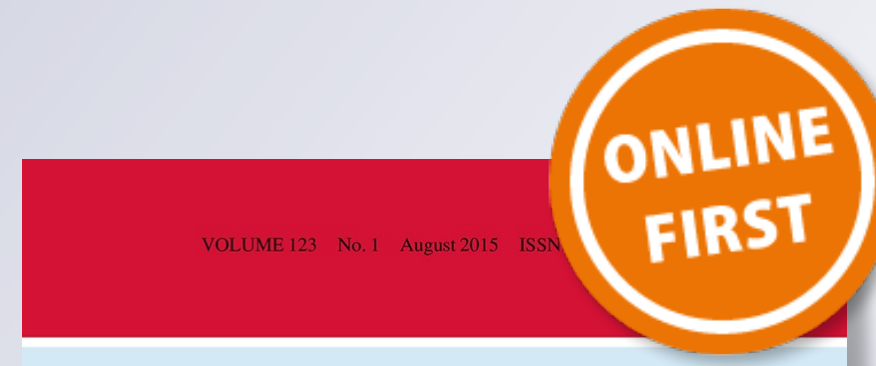

SOCIAL INDICA TORS R ESE A R C H

AN INTERNATIONAL AND

INTERDISCIPLINARY JOURNAL

FOR QUALITY-OF-LIFE MEASUREMENT

Editor: Filomena Maggino

\section{블 Springer}


Your article is protected by copyright and all rights are held exclusively by Springer Science +Business Media Dordrecht. This e-offprint is for personal use only and shall not be selfarchived in electronic repositories. If you wish to self-archive your article, please use the accepted manuscript version for posting on your own website. You may further deposit the accepted manuscript version in any repository, provided it is only made publicly available 12 months after official publication or later and provided acknowledgement is given to the original source of publication and a link is inserted to the published article on Springer's website. The link must be accompanied by the following text: "The final publication is available at link.springer.com". 


\title{
Can Corruption Erode Confidence in Political Institutions Among European Countries? Comparing the Effects of Different Measures of Perceived Corruption
}

\author{
Alessandro Pellegata ${ }^{1} \cdot{\text { Vincenzo } \text { Memoli }^{2}}^{2}$
}

Accepted: 6 July 2015

(C) Springer Science+Business Media Dordrecht 2015

\begin{abstract}
The purpose of this study is to analyze the effects of corruption on institutional confidence through testing alternative perceptions-based indexes of corruption. Scholars who have investigated this topic have often employed only indicators of corruption based on experts' surveys. In this article we also consider a new index of corruption developed aggregating citizens' perceptions. The first part of the paper explores the levels of corruption perceived by the citizens of EU member states, stressing the differences with the experts' opinions. The second part tests, through a multivariate analysis, the impact of citizens' and experts' perceptions-based indexes of corruption on institutional confidence. The main results show that experts and citizens tend to express similar opinions on the extent of corruption in EU member states though, especially in some countries, these actors present some noticeable differences. Nevertheless, irrespective of the indexes used, more corrupt countries are characterized by lower levels of confidence in parliament and government. This relationship holds even controlling for the presence of reverse causality between corruption and confidence.
\end{abstract}

Keywords Corruption - Confidence - Perception-based indexes · Political institutions · Political Support

Alessandro Pellegata

alessandro.pellegata@unimi.it

Vincenzo Memoli

memoli@unict.it

1 Department of Social and Political Sciences, Università degli Studi di Milano, Via Conservatorio, 7, 20122 Milan, Italy

2 Department of Political and Social Sciences, Università degli Studi di Catania, Via Vittorio Emanuele II, 8, 95131 Catania, Italy 


\section{Introduction}

Since the 1990s there has been a growing worldwide awareness with regard to the detrimental consequences of political corruption on economic growth (Mauro 1995) and the quality of governance (Kaufmann et al. 1999). Poor political and economic performances may reduce public support for democratic institutions (e.g. Mishler and Rose 2001; Anderson and Tverdova 2003). Lack of confidence in the honesty and the transparency of politicians may have dangerous effects on the functioning of representative democracies. Mistrust undermines political participation and alienates citizens from the policymaking process. Furthermore, it may generate a vicious circle because low institutional confidence could induce citizens and firms to resort to alternative resources to "get things done", with substantial negative consequences on the efficiency of government institutions and the survival of democratic regimes (della Porta 2000; Uslaner 2004).

Although in the last two decades several studies have investigated the effects of corruption on public support for political institutions and the way democratic process works, different relevant problems remain unsolved. Corruption is a complex and vague phenomenon that assumes different connotations in different cultural contexts (Lancaster and Montinola 1997). Moreover, corrupt interactions, being clandestine, are difficult to monitor and report. Corruption may remain hidden and invisible to the public and its actual extent in the different branches of the public sector is very difficult to estimate (della Porta 2000). All of these concerns are reflected in the difficulty to measure corruption in a comparative setting. As a consequence, there is an increasing debate, fueled by the availability of new survey data, about the validity and the reliability of different indicators of corruption, these being developed based on perceptions or actual experiences (Lancaster and Montinola 2000; Ko and Samajdar 2010).

The purpose of this study is twofold. In the first part, the article aims to compare the most common indexes of corruption which rely on the perceptions of country experts and international businessmen, with a newly developed indicator aggregating the mass perceptions taken from the Eurobarometer, stressing their analogies and differences.

In recent years there is a huge debate around the use of more objective measures of corruption based on the actual experiences suffered by citizens instead of their perceptions. However, there are several reasons according to which we have decided to focus our study on subjective indicators. First, the comparison of different perceptions-based indicators is a relatively neglected topic. Second, we think that experience-based measures are not free from potential biases and measurement errors. As Ko and Samajdar (2010) argued, people who are less educated, resident in rural areas, older and poorer respondents would be less sensitive to corruption than other groups. Third, a respondent might inaccurately generalize based on his own experience with a particular aspect of corruption (Donchev and Ujhelyi 2007). Fourth, experience-based measures capture street-level or "petty" corruption while it is presumable that citizens' confidence on institutions is more influenced by their perceptions of the level of "grand" corruption that invest the highest levels of government and that with difficulty they can encounter (Mishler and Rose 2008). Finally, as Treisman (2007) noted, even if we note that perceptions do not estimate the actual level of corruption, it is still worth studying them because they can have powerful effects, probably more than experience-based indicators, on the citizens' confidence in democratic institutions.

A further purpose of the article is to test the empirical performance of these different perceptions-based indicators in a multilevel analysis of institutional confidence. 
It improves the existing evidence on the relationship between corruption and institutional confidence offering three main contributions. First, while previous analyses focused on Western European democracies (Criado and Herreros 2007; Wagner et al. 2009) or post-communist countries of Central and Eastern Europe (Mishler and Rose 2001; Wallace and Latcheva 2006), the present study is conducted on a sample composed by the twenty-seven European Union (EU) member states. In our opinion EU constitutes an interesting area for the investigation of the effects of corruption on political support because it is composed by both mature and newly established democracies and presents a high degree of variation according to both the levels of corruption and of political support. The focus on EU member states assumes further importance because this study relies on individual responses to two different surveys conducted in late 2009, when the international economic and financial crisis had already exploded. The potential political instability generated by the economic crisis can provide a fertile breeding ground for the abuse of power by bureaucrats aware of the existing institutional inefficiencies.

Second, before testing the effects of corruption on institutional confidence, we outline EU member states respondents' opinions on different aspects of corruption, employing a Multiple Correspondence Analysis (MCA) on different variables obtained by the responses citizens gave to several questions taken from the Eurobarometer. Successively, starting from the individual respondents' perceptions, we develop, through a factor analysis, an aggregate index of corruption at the country level which allows us a deeper comparison with the indicators developed based on experts' surveys.

Third, we address the reciprocal causality between corruption and institutional confidence, a problem largely ignored by the existing literature, recurring to an empirical strategy proposed by Clausen et al. (2011) that is alternative to the instrumental variables model which relies on the supposed validity of exclusion restrictions that scholars (e.g. Chang and Chu 2006; Cho and Kirwin 2007) most often fail to adequately justify (Sovey and Green 2011).

What emerges from the empirical analysis that follows is that, though in general experts and common citizens tend to express similar opinions on the extent of corruption, these present some noticeable differences. Two divergent tendencies are in act, while in some countries common citizens, compared to experts, tend to over-estimate the problem of corruption, in other cases they tend to under-estimate the extent of this phenomenon. Nevertheless, both experts' and general public's indexes of corruption have a negative and significant impact on citizens' institutional confidence. Even though a vicious circle between corruption and confidence is present, the significant trust-eroding impact of corruption is unlikely to be overturn by the reverse causation effect.

The rest of the paper proceeds as follows. The next section reviews the related literature and the following one defines the two phenomena investigated, corruption and institutional confidence, and the relationship between them. In the fourth section we conduct a descriptive analysis of the citizens' perceptions of corruption in EU member states and we compare them with various experts' opinions. The fifth section describes the data, the variables, the methodology used in the multivariate analysis and its results. Moreover, it presents the results of the robustness check employed to address the reciprocal causality concern. Finally, in the last section we draw several concluding remarks. 


\section{Related Literature}

In the last decade the literature provided empirical evidence outlining a negative impact of corruption on political support. These studies present important methodological differences, in particular regarding the sample of countries analyzed and the strategy adopted to measure corruption. Regarding the operationalization of corruption there are three main streams of literature which rely on perceptions of or experiences with corruption measured at the country-level or individual-level.

A first group of studies measure corruption at the aggregate country level relying on the perceptions of country experts and businessmen collected in polls and surveys, such as the Transparency International's Corruption Perceptions Index (CPI) and the World Bank's Control of Corruption Index (CC). ${ }^{1}$ Among them, Anderson and Tverdova (2003) conducted a study on a sample of sixteen countries which included both Western democracies and Eastern European regimes. The authors show that corruption is negatively correlated with political support and that its trust-eroding effect is attenuated among supporters of incumbent political authorities. Wagner et al. (2009) performed a panel analysis on sixteen Western European countries in the time span 1990-2000. Their findings show that more efficient and less corrupt institutions are positively correlated with the citizens' levels of satisfaction with democracy.

A second group of studies rely on household-level variation in survey responses to questions about citizens' perceptions of corruption in the public sector. These studies include Mishler and Rose (2001) and Wallace and Latcheva (2006) who demonstrated that in post-communist countries of Eastern and Central Europe and the former Soviet Union high levels of corruption diminishes citizens' political support. Chang and Chu (2006) instead studied the relationship between corruption and institutional confidence in five emerging and consolidated Asian democracies. Their findings demonstrated a trust-eroding effect of corruption even in Asian countries that, according to many commentators, present contextual factors that should mediate the negative impact of corruption.

The third group of papers operationalized corruption using, instead, individual-level data based on personal experiences with bribery. Seligson (2002) provided empirical support for a negative effect of corruption on political support in four Latin American countries, while Cho and Kirwin (2007) reached the same conclusions in a set of seventeen sub-Saharan countries.

Finally, a more recent article by Clausen, Kraay and Nyiri (2011) presents several differences with the studies cited above. Focusing on a larger sample, composed by more than 100 countries, they simultaneously tested two different individual-level indicators of corruption, one based on citizens' perceptions and the other based on citizens' actual experiences.

\section{Linking Corruption and Institutional Confidence}

In this study we are interested in assessing the impact of corruption perceptions on citizens' confidence in political institutions. Institutional confidence has been usually considered an indicator of what Easton $(1965,1975)$ labelled "specific support". This indicates a form of support that is not related to a general attitude toward the political community or the

1 For information and data on CPI see www.transparency.org. CC and the other Worldwide Governance Indicators are available at http://info.worldbank.org/governance/wgi/index.asp. 
regime, but rather a support for the institutional outcomes and the results of the political authorities' actions. Given that the legitimacy of the institutions in the eyes of the citizens is heavily influenced by the political performance, we are primarily interested here in the citizens' confidence in two key institutions for the functioning of contemporary representative democracies, the parliament and the government.

In line with the existing literature, the main hypothesis advanced in this study is that corruption has a negative impact on citizens confidence in political institutions. In fact, several studies show that corruption hinders economic growth (Mauro 1995) and diminishes the quality of governance (Kaufmann et al. 1999).

Corruption is a complex phenomenon that is difficult to capture in a single definition. Lancaster and Montinola (1997) reviewed several definitions of corruption and discussed the benefits of adopting one definition or another depending on the nature of the social inquiry. As Andersson and Heywood (2009) suggested, given that it encompasses a wide range of activities, it is more useful to define corruption in generic terms. In this study we adopt a narrow definition, commonly accepted in comparative political studies, which considers corruption as "the misuse of public office for private financial gain" (e.g. RoseAckerman 1999; Treisman 2000; Warren 2004). This definition conceptualizes corruption as a deviation of legal and social norms and moral standards sanctioned by the public (Lancaster and Montinola 1997). More precisely, it indicates that, even though there are different activities that can be qualified as corrupt, each of them typically involves elected officials and/or appointed bureaucrats who abuse the power and authority with which they have been entrusted for private gain. Such activities take place at the expense of the collective community, thereby violating the norms that regulate public office (Warren 2004; Pellegata 2013).

When public agents are committed to deriving personal gain from their privileged positions, human, social, and economic resources are diverted from the public interest undermining the principles of democratic accountability and of fairness and impartiality of political institutions. When corruption is endemic, institutions become rent-seeking instruments in the hands of the political and economic elite, while the public is compelled to pay the externalities of this misallocation process consisting in a distortion of public demand, an increase of the cost and a reduction of the quality of public services (della Porta 2000). In sum, corrupt institutions mean inefficient institutions that presumably lose their credibility in the eyes of the citizens and contribute to generate disaffection and mistrust toward politics.

\section{Measuring Corruption Through Perceptions: But Perceptions of Whom?}

Two perceptions-based indicators are usually adopted to measure corruption in comparative studies. CPI is an annual index that measures how corrupt the public sector is perceived to be. It is released since 1995 and in 2009 covers 180 countries. This ranges between 0 , indicating highly perceived corruption, and 10, which means low levels of corruption. CC measures the extent to which public power is exercised for private gains, including both petty and grand forms of corruption, as well as "capture" of the state by elites and private interests. It is collected every 2 years from 1996 to 2002 and every year since 2003 for more than 200 countries and territories. CC ranges from -2.5 (more corruption) to +2.5 (less corruption). 
Both CPI and CC are developed aggregating a large number of partially similar individual data sources including polls of experts, surveys of businessmen, senior managers and individuals and the assessments of commercial risk agencies, non-governmental organizations, and multilateral aid agencies. CC combines elite and mass perceptions but gives much greater weight to elite perceptions. This is why there is a scholarly agreement that both CPI and CC tend to reflect the perceptions of corruption of the economic elite of different countries and the international private sector (see Mishler and Rose 2008; Andersson and Heywood 2009). Unsurprisingly, among EU member states in 2009 CPI and $\mathrm{CC}$ are almost perfectly correlated $(\mathrm{r}=0.9882)$.

But which is the opinion of the common citizens residents in EU member states on corruption? To answer to this question we have relied on the Eurobarometer 72.2 released in September 2009. More precisely, responses to seven different questions allow us to map citizens' opinions about the extent of corruption at different institutional levels, their experiences with bribe solicitations, the main reasons of the phenomenon and the efforts that institutions make to constrain it. $^{2}$ We have applied a MCA to synthesize the information contained in all these indicators, which refer to different aspects of the phenomenon. ${ }^{3}$ The MCA can be understood as a generalization or an extension of principal component analysis (PCA), when the variables, as in our case, are categorical (Adbi and Valentine 2007; Le Roux and Rouanet 2004). It is a tool which aims to explore and represent underlying structures in large datasets, and to describe and visualize multiplechoice data.

This technique has allowed us to reduce the wide range of variables considered here into a more limited number of factors. More specifically, MCA consists in the application of the CA algorithm to multivariate categorical data coded in the form of an indicator matrix or a Burt matrix (Greenacre and Pardo 2005). Through its application it is possible to represent the data as clouds of points in a multidimensional Euclidean space, where all variables/ units of analysis are represented by a point in a low-dimensional space. The results are interpreted on the basis of positions and proximity of points and their distribution along the underlying dimensions identified. The result was a bi-dimensional space with two factors that explain $94.2 \%$ of the total variance. ${ }^{4}$

In the graphic representation reported in Fig. 1 these two factors correspond to the two axes. The horizontal axis tells us the citizens' perceptions of how corruption is diffuse in different levels of government (local, regional and national level) and with reference to different figures of the public sector (politicians and bureaucrats). Moving from the left to the right of the horizontal axis means that the level of perceived corruption among citizens increases. The vertical axis refers instead to the responsibility of and the efforts made by the institutions in fighting corruption. European citizens who perceive a more widespread corruption in different bodies of the public sector are located in the lower-right side of the graph, whereas in the upper-left side are located those citizens who positively consider the efforts made by institutions in fighting corruption. The first factor (horizontal axis) explains

\footnotetext{
${ }^{2}$ More precisely, we have used questions from QB1 to QB7 included in Eurobarometer 72.2. The text of the questions can be found in the EB72.2 basic bilingual questionnaire (pp. 15-20), available from: https://dbk. gesis.org/dbksearch/SDesc 2 .asp?1l=10\&notabs=\&af=\&nf=\&search=\&search2=\&db=E\&no=4976.

3 The active variables, which contribute to the formation of the axes factors, included in our MCA are 90 . In this analysis we have not considered the variables which modalities presented a frequency percentage less than 2 .

4 Since eigenvalues obtained by MCA give a pessimistic evaluation of the variability explained by factorial axes, we have computed the variance considering only eigenvalues higher than $1 / \mathrm{k}$, where $\mathrm{k}$ is the number of variables used in the analysis.
} 


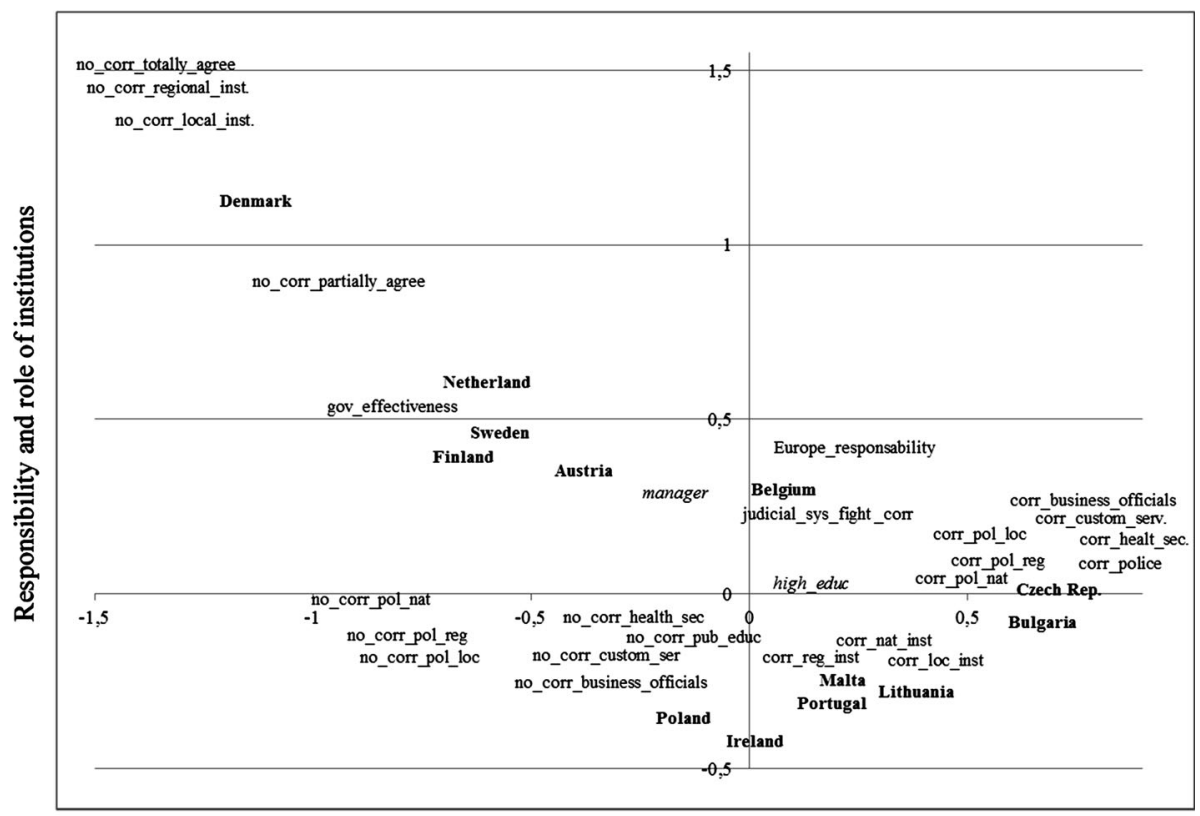

Spread of corruption at different levels of the public sector

Fig. 1 Perceptions of EU member states' citizens on different aspects of corruption

$87.2 \%$ of the total variance and the second factor (vertical axis) $7 \%$ of it. The distance of different modalities from the center of the two factorial axes tells us how much they contribute to the definition of the axes. Table 5 in the "Appendix" reports the labels of all the variables' modalities included in Fig. $1 .^{5}$

As we can note, citizens' perceptions of corruption at the different levels of governments tend to move together. Citizens who consider corruption as a major problem in their country think that it is widespread both at the national level and in the regional and local institutions. Moreover, these citizens think that corruption is particularly diffuse especially among politicians and the police, as well as in the public health and the business sectors of bureaucracy. Focusing on the vertical axis of the graph, we can note that European citizens think that the prevention from and the fight of corruption is mainly a responsibility of EU institutions and the judicial system.

This preliminary analysis of the general public's opinions regarding corruption confirms that there is a high variability among different EU members states. People who live in countries characterized by high levels of civic culture and a good institutional performance, such as Scandinavian and north continental countries (e.g. Denmark, Sweden, Finland and Netherlands), perceive very low levels of corruption and are satisfied of how institutions constrain the potential problems generated by this phenomenon. On the contrary, citizens of countries where the economy has low performances and the social capital does not reach high levels, such as Eastern and Southern European countries (e.g. Bulgaria,

\footnotetext{
5 Figure 1 does not report the position of those modalities and countries that collapse in the center of the two axes.
} 
Lithuania and Portugal) consider corruption a major problem, diffused among different institutional sectors.

To better compare mass perceptions of corruption with the experts' opinions measured by CPI and CC we develop a country-level index of corruption aggregating the answers citizens gave to a specific question included in the Eurobarometer. To be precise, this question asked EU citizens if they agree or disagree with three different statements affirming that there is corruption in local, regional and national institutions, respectively. ${ }^{6}$ We focus on these statements because they allow us to explicitly monitor citizens' perceptions of the spread of corruption in the public sector. This choice makes the index we have developed as similar as possible to the experts' perceptions-based indexes, such as CPI and CC, increasing their comparability. Applying a factor analysis to the citizens' responses we obtain a continuous index (factor score)-that we call Corruption-Eurobarometer (CEB) - which attributes a score to every country included in the sample measuring the average level of citizens' perceived corruption. As for CPI and CC, the higher the level of CEB, the lower the level of corruption.

Figure 2 shows two graphs which combine the general public's view on the extent of corruption in their country, as expressed by CEB, with the experts' perceptions, reflected in $\mathrm{CPI}$ and $\mathrm{CC}$, respectively. As we can see, mass perceptions are positively, though not linearly, related with the view that emerges from experts' surveys: the greater the perceptions of corruption expressed by the citizens of different countries, the greater the perceptions of the experts. The Spearman's rank correlation index between CEB and CPI is $\rho_{\mathrm{s}}=0.8335$, while between CEB and CC is $\rho_{\mathrm{s}}=0.8208$.

This result seems to contradict the claim which affirms that indicators based on experts' opinion are disconnected from those of the general public (Kaufmann et al. 1999). At the same time, it also disproves another common wisdom claiming that common citizens, differently from experts, cannot really assess the actual extent of corruption in their country's public institutions (Kaufmann and Wei 1999). What emerges from this preliminary analysis is that experts' and citizens' perceptions tend to move in the same direction.

Nevertheless, in spite of these analogies, there are also some differences between experts' and citizens' perceptions that is worth discussing. In fact, though quite high, the correlation between these two groups of indexes is far from being perfect. It is worth noting that, as identified by the curve that best fits the data distribution at the country level, there is a "concave" relationship between experts-based and mass-based indexes. In general terms this indicates that experts are more reluctant than citizens to attribute very high scores to cleaner countries.

Figure 3 presents three box plots that depict the data distributions of CPI, CC and CEB, respectively. Whereas the distributions of CPI and CC in our sample are more homogeneous, CEB concentrates almost all the countries at the bottom of the scale. The five less corrupt political systems (Denmark, Netherlands, Luxembourg, Sweden and Austria) instead are outliers in the distribution of CEB. This means that, differently from experts, citizens of these countries perceive levels of corruption that are much more lower than the levels perceived by the citizens of the other twenty two countries included in the sample.

\footnotetext{
${ }^{6}$ We have used the QB1 (see note 3 for the related documentation). QB1 is the following: "For each of the following statements, could you please tell me whether you totally agree, tend to agree, tend to disagree or totally disagree with it. There is corruption in local/regional/national institutions in [country]." We have dichotomized original answers in the following way: "totally agree" and "tend to agree" in the category "agree" (0) and "tend to disagree" and "totally disagree" in the category "disagree" (1).
} 

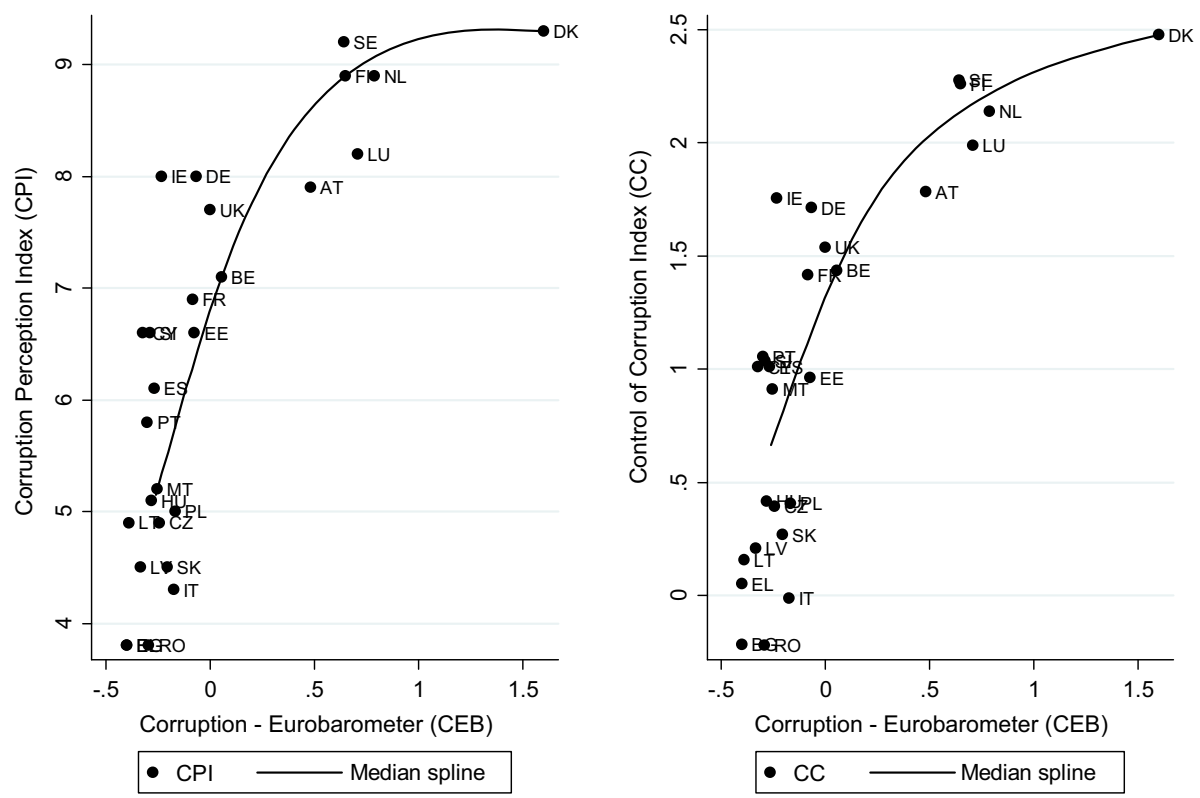

Fig. 2 Relationship between the perceptions of corruption expressed by citizens (CEB) and by experts (CPI and $\mathrm{CC}$ )
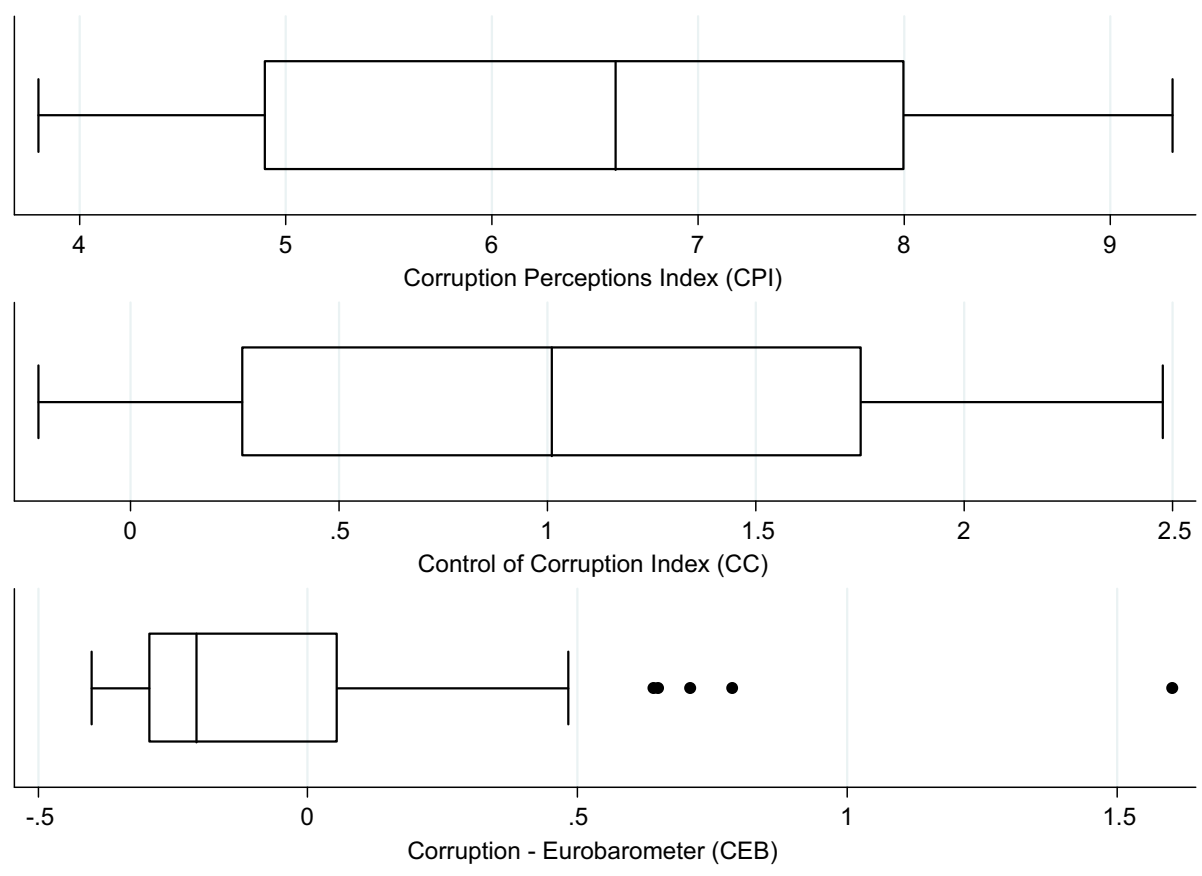

Fig. 3 Box plots of the distribution of CPI, CC and CEB among the twenty seven countries of our sample 
The image depicted in Fig. 3 seems to give support to one of the main critique moved toward the use of mass perceptions-based indexes of corruption in comparative studies. It is often argued that citizens tend to make in-context or country-specific interpretations of the phenomenon of corruption. In particular, it is contested the fact that common citizens tend to over-estimate the extent of corruption in their country making exaggerations of the reality (Kaufmann and Wei 1999). An in-depth comparison of the ranking of the sample countries according to the three indexes proposed can help to shed light on this problem.

Table 1 ranks the twenty seven EU member states according to the values attributed to them by CPI, CC and CEB, respectively. Horizontal lines delimit the quartiles of the distributions. While the rankings based on CPI and CC are almost the same, the ranking of countries based on CEB shows some non-negligible differences from the second to the fourth quartile of the distribution.

Table 1 Country rankings according to different corruption indexes (CPI, CC and CEB)

\begin{tabular}{|c|c|c|c|c|c|}
\hline Country ranking & CPI & Country ranking & $\mathrm{CC}$ & Country ranking & CEB \\
\hline Denmark & 9.3 & Denmark & 2.478 & Denmark & 1.603 \\
\hline Sweden & 9.2 & Sweden & 2.276 & Netherlands & 0.787 \\
\hline Finland & 8.9 & Finland & 2.261 & Luxembourg & 0.710 \\
\hline Netherlands & 8.9 & Netherlands & 2.138 & Finland & 0.650 \\
\hline Luxembourg & 8.2 & Luxembourg & 1.987 & Sweden & 0.642 \\
\hline Germany & 8 & Austria & 1.783 & Austria & 0.482 \\
\hline Ireland & 8 & Ireland & 1.754 & Belgium & 0.055 \\
\hline Austria & 7.9 & Germany & 1.714 & United Kingdom & -0.001 \\
\hline United Kingdom & 7.7 & United Kingdom & 1.537 & Germany & -0.067 \\
\hline Belgium & 7.1 & Belgium & 1.437 & Estonia & -0.075 \\
\hline France & 6.9 & France & 1.416 & France & -0.083 \\
\hline Cyprus & 6.6 & Portugal & 1.056 & Poland & -0.167 \\
\hline Estonia & 6.6 & Slovenia & 1.035 & Italy & -0.173 \\
\hline Slovenia & 6.6 & Spain & 1.012 & Slovakia & -0.206 \\
\hline Spain & 6.1 & Cyprus & 1.010 & Ireland & -0.233 \\
\hline Portugal & 5.8 & Estonia & 0.963 & Czech Republic & -0.244 \\
\hline Malta & 5.2 & Malta & 0.912 & Malta & -0.253 \\
\hline Hungary & 5.1 & Hungary & 0.416 & Spain & -0.268 \\
\hline Poland & 5 & Poland & 0.409 & Hungary & -0.282 \\
\hline Czech Republic & 4.9 & Czech Republic & 0.393 & Slovenia & -0.288 \\
\hline Lithuania & 4.9 & Slovakia & 0.269 & Romania & -0.294 \\
\hline Latvia & 4.5 & Latvia & 0.209 & Portugal & -0.301 \\
\hline Slovakia & 4.5 & Lithuania & 0.158 & Cyprus & -0.323 \\
\hline Italy & 4.3 & Greece & 0.053 & Latvia & -0.335 \\
\hline Greece & 3.8 & Italy & -0.013 & Lithuania & -0.391 \\
\hline Bulgaria & 3.8 & Bulgaria & -0.216 & Greece & -0.401 \\
\hline Romania & 3.8 & Romania & -0.221 & Bulgaria & -0.401 \\
\hline Mean & 6.355 & Mean & 1.045 & Mean & 0.005 \\
\hline
\end{tabular}


Two important elements emerge comparing common citizens' and experts' perceptions. First, significant differences invest only few of the countries included in the sample. Second and more interestingly, there are two apparently contrasting tendencies in act. On one hand, in some countries (especially Cyprus, Ireland and Portugal) citizens effectively over-estimate the relatively low levels of corruption attributed to them by experts. On the other hand, citizens of countries such as Estonia, Poland, Slovakia and above all Italy, under-estimate the high levels of corruption attributed to them by the experts.

Different potential factors may explain why mass perceptions deviate from those of the elite. Several studies argue that perceptions of corruption are not driven by direct experiences with bribe solicitations, but rather by second-hand information on the extent of corruption in the public sectors (Donchev and Ujhelyi 2007; Mishler and Rose 2008). While businessmen and country experts could be more informed on the spread of corruption especially at the "grand" national and financial level, the common citizens' perceptions are probably strongly influenced by the effective knowledge they have about corruption. More educated and more informed respondents as well as citizens who live in bigger cities and are employed in the services may probably have a more precise idea of the actual extent of corruption in the public sector.

Furthermore, there are also some country-level factors that help explain the above mentioned deviations. Citizens living in one country share particular historic legacies and cultural traditions which vary from country to country. Corruption, being part of such historic and cultural traditions, take different forms and refer to different types of behavior in different contexts (Lancaster and Montinola 1997). The under-estimation of the extent of corruption by the citizens of Estonia, Poland and Slovakia in respect to those of the experts can be partially explained with the legacy of the past communist regimes. Lipset and Lenz (2000) and Sandholtz and Taagepera (2005) provide evidence that post-communist states are susceptible to corrupt practices both because of the heritage of the economic decisionmaking under communism and because of the vulnerability of privatization scheme to corrupt influences. After decades of communist rule corruption became "culturally embedded" and citizens of Eastern Europe are implicitly more indulgent toward corrupt practices than in Western and Northern Europe (Sandholtz and Taagepera 2005).

\section{Multilevel Analysis}

\subsection{Data and Methods}

The multivariate analysis is conducted on a dataset that combines more than 23,400 observations at the individual level of respondents nested with information at the country level. The combination of this two levels of information lead us to employ a multilevel modeling procedure that takes into account the hierarchical nature of our data. ${ }^{7}$ To estimate

\footnotetext{
7 We have run a null model without country-level or individual-level predictors which allows us to decompose the total variance in our dependent variables between individual and country levels. From the value of intra-class correlation we can infer that country-level variance ranges between the $18 \%(\mathrm{CON}-$ FGOV) and the $20 \%$ (CONFPARL) of the total variance. In other words, around the $20 \%$ of the difference in the level of institutional confidence can be explained by the fact that a respondent lives in one country instead of another.
} 
the models we run a set of random intercept GLS regressions with heteroskedasticityconsistent standard errors. ${ }^{8}$

The dependent variable in our analysis is represented by two indicators that measure the citizens' confidence in the parliament (CONFPARL) and the government (CONFGOV). These measures are gathered from the answers that respondents have given to a question included in the Eurobarometer 72.1 of September 2009. ${ }^{9}$ These goes from 1, no trust at all in parliament (government), to 10, trust completely in parliament (government).

The independent variable is corruption control and is operationalized through the three aggregate perceptions-based indexes described above: CPI, CC and CEB. The higher the level of these three indexes, the lower the level of corruption.

To address the omitted factor bias we have introduced in the multivariate analysis a set of control variables both at the country and at the individual level. Constitutional design (MAJ) refers to the countries' political-institutional framework and is operationalized with the index of majoritarianism on the executive-parties dimension developed by Lijphart (1999), which captures the consensual or majoritarian pattern of democracy. MAJ ranges from 0 to 4, being 0 the lower level of majoritarianism and 4 the higher level. ${ }^{10}$ Differently from majoritarian systems, where the power is concentrated in the hands of the incumbents, in consensual democracies it is dispersed among different political forces and institutions and, consequently, the attribution of responsibility for the economic outcomes is much more obscure (Lijphart 1999; Powell 2000). As Criado and Herreros (2007) argued, this implies two elements. First, in consensual democracies the impact of economic performance on evaluations of governments is lower. Second, in these political systems support for the institutions by those citizens ideologically distant from the incumbents is higher than in majoritarian democracies. Therefore, people who live in predominantly consensual democracies should display higher levels of institutional confidence than those who live in predominantly majoritarian systems.

New democracies (NEWDEM) is a dummy variable that assumes value of 1 for those political systems in which democracy has not been in place for at least 25 years, that in our sample coincide with the ten East European countries. As we have previously seen, postcommunist countries tend to present lower levels of both institutional confidence and corruption control than mature democracies. Unconsolidated party systems, unstable governments and the legacy that especially older people feel with the past regime lead us expect new democracies to be negatively associated with citizens' institutional confidence (Linz and Stepan 1996: 55-65). Moreover, as Horowitz et al. (2009) have shown, the impact of corruption on the quality of democracy and the regime legitimacy is more evident in hybrid regimes and young democracies where a confuse and unstable political context leaves more discretional power to politicians and bureaucrats, who can abuse of their positions to obtain private financial gain.

\footnotetext{
${ }^{8}$ Because both the dependent variables are indexes and could be treated as approximation of continuous variables, the models are estimated by the xtreg command in STATA. We have run the Hausman test to compare the performance of the fixed and the random effect models. The result suggests the use of random effects models.

9 The question used is the following: "Please tell me how much you personally trust [NATIONALITY] parliament(government) using a scale from 1 to 10 where [1] means 'you do not trust the institution at all' and [10] means 'you trust it completely'".

10 The procedure used to obtain MAJ is exactly the same described in Lijphart (1999: 243-250). The original Lijphart's dataset has been updated using different sources. Data on electoral results, parliaments and governments composition are gathered from ParlGov Dataset (www.parlgov.org), while data on the index of corporativism are taken from Siaroff (2003) and Roberts (2006).
} 
The economic performance of the sample countries is operationalized with the natural logarithm of GDP per capita in 2009 (logGDP) and the average degree of GDP growth in the last 5 years as a percentage of GDP (GDPG). ${ }^{11}$ According to the findings obtained by past studies, we expect that higher levels of per capita income and economic growth will be associated with higher institutional confidence.

At the individual level we have controlled the effects of corruption for the impact of several demographic and socio-economic variables included in the Eurobarometer 72.1 where we have gathered CONFPARL and CONFGOV. Life satisfaction (LIFESAT) ranges from 0 for those people very dissatisfied for the quality of their life to 10 for those people that are instead very satisfied. Financial expectation (FINANCEXP) is a ordinal variable that attributes different values to those people who think that their household's financial situation will be worse (1), the same (2) or better in the next 12 months (3). Social level (SOCLEV) is gathered from an item that asks people to place themselves on a scale that goes from 0 (lowest level) to 10 (highest level) in accordance to their level in the society. We expect that people more satisfied of their life, people trusting that their household's financial situation will be better in the future and people that place themselves in the highest levels in the society will be more confident with political institutions. Moreover, we also include in the analysis other three socio-demographic variables. AGE simply measures the age of respondents if they are at least 18 years old, while GENDER is a dummy variable that assumes value of 1 for females and 0 for males. EDUCATION measures the age of respondents when they stopped full-time education.

Table 2 reports descriptive statistics of all the variables tested in the following empirical models.

\subsection{Empirical Results}

Table 3 shows the results of six regression models. The first three models test the effects of corruption, measured with CEB, CPI and CC, respectively, on CONFPARL, while Models 4, 5 and 6 test the effects of the same three indicators of corruption on CONFGOV. All the six models include both the country-level and the individual-level control variables described above.

As we have hypothesized, the capacity of political systems to control corruption positively and significantly affects the citizens' confidence both in the parliament and the government. Citizens who live in political systems perceived as less corrupt show higher levels of confidence in their key political institutions. In the six models tested the trusteroding impact of corruption is always significant, irrespective of whether we measure corruption with mass perceptions or with data gathered from experts' surveys. In other words, in assessing the effects of corruption on institutional confidence to adopt a bottomup (CEB) or a top-down (CPI and CC) approach produces the same result: the higher the value of the indexes (meaning lower levels of perceived political corruption), the higher the level of confidence in the parliament and the government. ${ }^{12}$

\footnotetext{
11 Data for these two variables are taken from World Development Indicators. See http://data.worldbank. org/data-catalog/world-development-indicators.

12 As a robustness check we have also run additional models which contemporaneously test CEB and CPI as well as CEB and CC. We have not included CPI and CC in the same models because they are almost perfectly correlated. Results are available upon request. In all these models only CEB displays a positive and significant effect on both CONFPARL and CONFGOV, whereas CPI and CC turn to be insignificant. Given that institutional confidence is directly gathered from ordinary citizens' opinions, it is not unsurprising that only CEB, which is measured based on different country residents' perceptions, is significantly related to confidence. This result represents a further confirmation of the validity of our new corruption measure and
} 
Table 2 Descriptive statistics

\begin{tabular}{llrrrc}
\hline Variable & Observations & \multicolumn{1}{c}{ Mean } & \multicolumn{1}{c}{ SD } & Min & Max \\
\hline Confidence in parliament (CONFPARL) & 26,073 & 4.1908 & 2.4236 & 1 & 10 \\
Confidence in government (CONFGOV) & 26,204 & 4.2076 & 2.4840 & 1 & 10 \\
Corruption-Eurobarometer (CEB) & 26,719 & 0.0225 & 0.4691 & -0.401 & 1.602 \\
Corruptions Perceptions Index (CPI) & 26,719 & 6.3799 & 1.7773 & 3.799 & 9.3 \\
Control of Corruption Index (CC) & 26,719 & 1.0469 & 0.8177 & -0.221 & 2.477 \\
New democracy (NEWDEM) & 26,719 & 0.3796 & 0.4853 & 0 & 1 \\
Majoritarian system (MAJ) & 26,719 & 1.9919 & 0.6700 & 0.944 & 3.702 \\
Natural log of GDP per capita (logGDP) & 26,719 & 8.3946 & 3.7634 & 0 & 10.931 \\
Gdp Growth (GDPG) & 26,719 & 2.2839 & 1.8389 & 0 & 5.511 \\
Household financial expectation (FINEXP) & 25,536 & 1.9734 & 0.6232 & 1 & 3 \\
Life satisfaction (LIFESAT) & 26,654 & 6.6792 & 2.2472 & 1 & 10 \\
Gender (Female) & 26,719 & 1.5533 & 0.4971 & 1 & 2 \\
Age & 25,852 & 49.1834 & 17.8746 & 18 & 98 \\
Education & 26,234 & 17.0093 & 6.9809 & 0 & 66 \\
Level in the society (SOCLEV) & 26,171 & 5.5980 & 1.5855 & 1 & 10 \\
\hline
\end{tabular}

Among the country-level factors tested, only NEWDEM is significantly related with both the dependent variables. As expected, in young democracies of Eastern Europe, citizens are more distrusted toward political institutions than in more consolidated democratic systems. Moreover, the trust-eroding effects of corruption is not driven by the presence in the sample of the post-communist countries which present comparatively high levels of corruption, according to the perceptions both of the experts and of the general public. Although the direction of the relationship between MAJ and the dependent variables is the expected one, its regression coefficient is never statistically significant in any of the models tested. The institutional framework (consensual Vs majoritarian systems) does not affect the citizens' institutional confidence. Although economic performance is considered one of the most relevant factors that influence citizens' support for public institutions, our results show that neither logGDP nor GDPG have a significant effect on our dependent variables.

On the contrary, at the individual-level several control variables display a significant effect on institutional confidence. Citizens who expect that their household's financial situation will be more prosperous in the next twelve months (FINEXP), are more satisfied for their life in general (LIFESAT) and place themselves in a higher level in the society (SOCLEVEL) are more trustful toward the parliament and the government than people who live in harder conditions. A possible explanation of these different results between country-level and individual-level economic factors is given by Banducci et al. (2003) and Hobolt and Leblond (2009) which argued that support for political institutions is determined by both socio-tropic and egocentric motives. Although citizens are concerned with

Footnote 12 continued

points out that experts' perceptions based measures can be flawed in explaining confidence, recommending the necessity to use different corruption measures in future analyses. However, scholars should be careful of this result because it can be ascribed to a problem of collinearity among different corruption measures. Given the high level of correlation between CEB and CPI/CC, it is most likely that CEB "absorbs" all the significance of the relation between corruption and institutional confidence. 
Table 3 Determinants of institutional confidence in parliament (CONFPARL) and government (CONFGOV)

\begin{tabular}{|c|c|c|c|c|c|c|}
\hline & \multicolumn{3}{|c|}{$\begin{array}{l}\text { Confidence in Parliament } \\
\text { (CONFPARL) }\end{array}$} & \multicolumn{3}{|c|}{$\begin{array}{l}\text { Confidence in Government } \\
\text { (CONFGOV) }\end{array}$} \\
\hline & Model 1 & Model 2 & Model 3 & Model 4 & Model 5 & Model 6 \\
\hline \multicolumn{7}{|l|}{ Country level } \\
\hline $\begin{array}{l}\text { Corruption- } \\
\text { Eurobarometer (CEB) }\end{array}$ & $\begin{array}{l}1.031 * * * \\
(0.2296)\end{array}$ & & & $\begin{array}{l}0.9558 * * * \\
(0.3192)\end{array}$ & & \\
\hline $\begin{array}{l}\text { Corruption Perceptions } \\
\text { Index (CPI) }\end{array}$ & & $\begin{array}{l}0.1902 * * \\
(0.0788)\end{array}$ & & & $\begin{array}{l}0.1804 * \\
(0.0939)\end{array}$ & \\
\hline $\begin{array}{l}\text { Control of Corruption } \\
\text { Index (CC) }\end{array}$ & & & $\begin{array}{l}0.4705 * * * \\
(0.1833)\end{array}$ & & & $\begin{array}{l}0.4459 * * \\
(0.2194)\end{array}$ \\
\hline $\begin{array}{l}\text { New Democracy } \\
\text { (NEWDEM) }\end{array}$ & $\begin{array}{l}-1.078 * * \\
(0.4179)\end{array}$ & $\begin{array}{l}-1.1174 * * \\
(0.4428)\end{array}$ & $\begin{array}{l}-1.0071 * * \\
(0.4408)\end{array}$ & $\begin{array}{l}-1.0304 * * \\
(0.4871)\end{array}$ & $\begin{array}{l}-1.0593^{* *} \\
(0.5279)\end{array}$ & $\begin{array}{l}-0.9550^{*} \\
(0.5210)\end{array}$ \\
\hline $\begin{array}{l}\text { Majoritarian system } \\
\text { (MAJ) }\end{array}$ & $\begin{array}{l}-0.0105 \\
(0.2192)\end{array}$ & $\begin{array}{l}-0.1961 \\
(0.1858)\end{array}$ & $\begin{array}{l}-0.2050 \\
(0.1782)\end{array}$ & $\begin{array}{l}-0.0243 \\
(0.2677)\end{array}$ & $\begin{array}{l}-0.1926 \\
(0.2186)\end{array}$ & $\begin{array}{l}-0.2012 \\
(0.2087)\end{array}$ \\
\hline $\begin{array}{l}\text { Natural log of GDP per } \\
\text { capita (logGDP) }\end{array}$ & $\begin{array}{l}0.0140 \\
(0.0264)\end{array}$ & $\begin{array}{l}0.0296 \\
(0.0343)\end{array}$ & $\begin{array}{l}0.0217 \\
(0.0349)\end{array}$ & $\begin{array}{l}-0.0023 \\
(0.0372)\end{array}$ & $\begin{array}{l}0.0120 \\
(0.0449)\end{array}$ & $\begin{array}{l}0.0045 \\
(0.0462)\end{array}$ \\
\hline GDP growth (GDPG) & $\begin{array}{l}0.0903 \\
(0.1309)\end{array}$ & $\begin{array}{l}0.0871 \\
(0.1435)\end{array}$ & $\begin{array}{l}0.0902 \\
(0.1430)\end{array}$ & $\begin{array}{l}0.1563 \\
(0.1653)\end{array}$ & $\begin{array}{l}0.1541 \\
(0.1722)\end{array}$ & $\begin{array}{l}0.1570 \\
(0.1723)\end{array}$ \\
\hline \multicolumn{7}{|l|}{ Individual level } \\
\hline $\begin{array}{l}\text { Household financial } \\
\text { expectations (FINEXP) }\end{array}$ & $\begin{array}{l}0.2676 * * * \\
(0.0392)\end{array}$ & $\begin{array}{l}0.2677 * * * \\
(0.0392)\end{array}$ & $\begin{array}{l}0.2677 * * * \\
(0.0392)\end{array}$ & $\begin{array}{l}0.3101 * * * \\
(0.0401)\end{array}$ & $\begin{array}{l}0.3102 * * * \\
(0401)\end{array}$ & $\begin{array}{l}0.3102 * * * \\
(0.0401)\end{array}$ \\
\hline $\begin{array}{l}\text { Life satisfaction } \\
\quad(\text { LIFESAT) }\end{array}$ & $\begin{array}{l}0.1736 * * * \\
(0.0109)\end{array}$ & $\begin{array}{l}0.1737 * * * \\
(0.0109)\end{array}$ & $\begin{array}{l}0.1737 * * * \\
(0.0109)\end{array}$ & $\begin{array}{l}0.1775^{* * * *} \\
(0.0096)\end{array}$ & $\begin{array}{l}0.1776^{* * *} \\
(0.0096)\end{array}$ & $\begin{array}{l}0.1776^{* * * *} \\
(0.0096)\end{array}$ \\
\hline Gender & $\begin{array}{l}-0.0334 \\
(0.0421)\end{array}$ & $\begin{array}{l}-0.0335 \\
(0.0421)\end{array}$ & $\begin{array}{l}-0.0335 \\
(0.0421)\end{array}$ & $\begin{array}{l}-0.0553 \\
(0.0380)\end{array}$ & $\begin{array}{l}-0.0553 \\
(0.0380)\end{array}$ & $\begin{array}{l}-0.0553 \\
(0.0380)\end{array}$ \\
\hline Age & $\begin{array}{l}0.0083 * * * \\
(0.0016)\end{array}$ & $\begin{array}{l}0.0083 * * * \\
(0.0016)\end{array}$ & $\begin{array}{l}0.0083^{* * * *} \\
(0.0016)\end{array}$ & $\begin{array}{l}0.0109 * * * \\
(0.0018)\end{array}$ & $\begin{array}{l}0.0109 * * * \\
(0.0018)\end{array}$ & $\begin{array}{l}0.0109 * * * \\
(0.0018)\end{array}$ \\
\hline Education & $\begin{array}{l}0.0019 \\
(0.0037)\end{array}$ & $\begin{array}{l}0.0019 \\
(0.0196)\end{array}$ & $\begin{array}{l}0.0019 \\
(0.0037)\end{array}$ & $\begin{array}{l}-0.0006 \\
(0.0036)\end{array}$ & $\begin{array}{l}-0.0005 \\
(0.0036)\end{array}$ & $\begin{array}{l}-0.0005 \\
(0.0036)\end{array}$ \\
\hline $\begin{array}{l}\text { Level in the society } \\
\text { (SOCLEV) }\end{array}$ & $\begin{array}{l}0.1930 * * * \\
(0.0196)\end{array}$ & $\begin{array}{l}0.1932 * * * \\
(0.0196)\end{array}$ & $\begin{array}{l}0.1932 * * * \\
(0.0196)\end{array}$ & $\begin{array}{l}0.2034 * * * \\
(0.0204)\end{array}$ & $\begin{array}{l}0.2035^{* * *} \\
(0.0204)\end{array}$ & $\begin{array}{l}0.2035 * * * \\
(0.0204)\end{array}$ \\
\hline Constant & $\begin{array}{l}1.1581 * * \\
(0.5800)\end{array}$ & $\begin{array}{l}0.2391 \\
(0.7140)\end{array}$ & $\begin{array}{l}0.9909 * \\
(0.5497)\end{array}$ & $\begin{array}{l}0.9735 \\
(0.7685)\end{array}$ & $\begin{array}{l}0.0853 \\
(0.8622)\end{array}$ & $\begin{array}{l}0.7993 \\
(0.6570)\end{array}$ \\
\hline R-sq & 0.2152 & 0.2017 & 0.2027 & 0.1763 & 0.1662 & 0.1670 \\
\hline Wald (sig.) & 0.0000 & 0.0000 & 0.0000 & 0.0000 & 0.0000 & 0.0000 \\
\hline Sigma_u & 0.5923 & 0.6357 & 0.6194 & 0.7257 & 0.7562 & 0.7452 \\
\hline Sigma_e & 2.0885 & 2.0885 & 2.0885 & 2.1776 & 2.1776 & 2.1776 \\
\hline Rho & 0.0744 & 0.0848 & 0.0808 & 0.0999 & 0.1076 & 0.1048 \\
\hline Number of observations & 23,478 & 23,478 & 23,478 & 23,569 & 23,569 & 23,569 \\
\hline Number of groups & 27 & 27 & 27 & 27 & 27 & 27 \\
\hline
\end{tabular}

Robust standard errors in parentheses

$* p<0.10 ; * * p<0.05 ; * * * p<0.01$

the economic situation of their country, they tend to care more about their personal socioeconomic conditions. Furthermore, Banducci et al. (2009) posited that the actual economic reality - as summarized in official economic statistics — does not necessarily agree with the 
economic situation perceived by different citizens. Finally, while GENDER and EDUCATION do not affect political support, AGE appears as a significant explanatory factor; older citizens display more confidence in the parliament and the government.

\subsection{Managing Endogeneity}

In the last section we have shown significant partial correlations between different measures of corruption and citizens' confidence in the parliament and the government. Nevertheless, there can be a problem of reciprocal causality between corruption and institutional confidence. Corruption can effectively lead to a loss of confidence, as shown thus far, but at the same time, respondents who report less confidence in institutions might perceive a more widespread corruption.

Several studies have addressed this major concern relying on simultaneous equations models in which corruption is instrumented on one or more factors that are correlated with it but not with institutional confidence (Chang and Chu 2006; Cho and Kirwin 2007). However, finding valid instruments is very difficult and the exclusion restrictions that scholars impose to them are often theoretically difficult to justify (see Sovey and Green 2011). For instance, Chang and Chu (2006) adopted citizens' media exposure as instrument of corruption, while Cho and Kirwin (2007) used generalized trust in others. Nevertheless, it is very hard to find convincing the claim that these factors are correlated only with corruption and have no direct effects on institutional confidence.

To overcome this problem we adopt an empirical strategy already used by Clausen et al. (2011) and based on Leamer (1981). Given that in this study the perceptions of corruption are measured at the aggregate level, in Table 4 we have run the same models presented in Table 3 but at the country level. Besides the three different indexes of corruption we have included only the control variables that were significant in the multilevel models reported in Table 3. FINEXP, LIFESAT, AGE and SOCLEVEL that are measured at the individual level were collapsed at the country level by taking means. Not surprisingly, CEB, CPI and $\mathrm{CC}$ are the only variables that are always significantly correlated with both CONFPARL and CONFGOV.

The problem of reverse causation can be explained by the following system of equations in which $\mathrm{y}$ and $\mathrm{x}$ depend on each other:

$$
\begin{aligned}
& y=\beta x+\varepsilon \\
& x=\gamma y+v
\end{aligned}
$$

let y denote the proportion of institutional confidence orthogonal to all the control variables present in Models 7 and 10 of Table 4, and let x denote the same orthogonal component of corruption. ${ }^{13}$ For the purpose of the study we are interested in assessing how the estimate of $\beta$, which represents the effects of corruption on confidence, changes given different assumptions on the strength of the reverse causation captured by $\gamma$. The estimator of $\beta$ conditional to $\gamma$ can be expressed by the three observable moments $(\mathrm{V}(\mathrm{x}), \mathrm{V}(\mathrm{y})$ and $\operatorname{COV}(\mathrm{x}, \mathrm{y}))$ in terms of the four unknown parameters $(\mathrm{x}, \mathrm{y} \text {, and the error terms } \varepsilon \text { and } v)^{14}$ :

\footnotetext{
${ }^{13}$ For simplicity we present the robustness checks only for CEB, but the same procedure has been also applied on the other corruption indexes. Graphs are available upon request.

14 For a more complete explanation of the algebra adopted in the following procedure we remand to Leamer (1981) and Clausen et al. (2011).
} 
Table 4 Corruption and institutional confidence at the country-level

\begin{tabular}{|c|c|c|c|c|c|c|}
\hline & \multicolumn{3}{|c|}{ Confidence in parliament (CONFPARL) } & \multicolumn{3}{|c|}{$\begin{array}{l}\text { Confidence in government } \\
\text { (CONFGOV) }\end{array}$} \\
\hline & Model 7 & Model 8 & Model 9 & Model 10 & Model 11 & Model 12 \\
\hline $\begin{array}{l}\text { Corruption- } \\
\text { Eurobarometer } \\
(\mathrm{CEB})\end{array}$ & $\begin{array}{l}1.2819 * * * \\
(0.3410)\end{array}$ & & & $\begin{array}{l}1.1902 * * \\
(0.4761)\end{array}$ & & \\
\hline $\begin{array}{l}\text { Corruption Perceptions } \\
\text { Index (CPI) }\end{array}$ & & $\begin{array}{l}0.3166 * * \\
(0.1197)\end{array}$ & & & $\begin{array}{l}0.2869 * \\
(0.1390)\end{array}$ & \\
\hline $\begin{array}{l}\text { Control of Corruption } \\
\text { Index (CC) }\end{array}$ & & & $\begin{array}{l}0.8279 * * * \\
(0.2844)\end{array}$ & & & $\begin{array}{l}0.7250 * * \\
(0.3303)\end{array}$ \\
\hline $\begin{array}{l}\text { New democracy } \\
\text { (NEWDEM) }\end{array}$ & $\begin{array}{l}-0.8611 * * * \\
(0.2852)\end{array}$ & $\begin{array}{l}-0.7275^{* *} \\
(0.2584)\end{array}$ & $\begin{array}{l}-0.5861 * * \\
(0.2701)\end{array}$ & $\begin{array}{l}-0.6524 * * \\
(0.3112)\end{array}$ & $\begin{array}{l}-0.5295^{*} \\
(0.2824)\end{array}$ & $\begin{array}{l}-0.4073 \\
(0.3087)\end{array}$ \\
\hline $\begin{array}{l}\text { Household financial } \\
\text { expectations } \\
\text { (FINEXP) }\end{array}$ & $\begin{array}{l}-0.0093 \\
(0.0252)\end{array}$ & $\begin{array}{l}0.0046 \\
(0.0265)\end{array}$ & $\begin{array}{l}0.0097 \\
(0.0244)\end{array}$ & $\begin{array}{l}-0.0102 \\
(0.0305)\end{array}$ & $\begin{array}{l}0.0025 \\
(0.0321)\end{array}$ & $\begin{array}{l}0.0067 \\
(0.0305)\end{array}$ \\
\hline $\begin{array}{l}\text { Life satisfaction } \\
\text { (LIFESAT) }\end{array}$ & $\begin{array}{l}-0.0877 \\
(0.3079)\end{array}$ & $\begin{array}{l}-0.4358 \\
(0.3823)\end{array}$ & $\begin{array}{l}-0.5489 \\
(0.3976)\end{array}$ & $\begin{array}{l}0.0096 \\
(0.3709)\end{array}$ & $\begin{array}{l}-0.2984 \\
(0.4521)\end{array}$ & $\begin{array}{l}-0.3766 \\
(0.4771)\end{array}$ \\
\hline Age & $\begin{array}{l}0.0492 \\
(0.0534)\end{array}$ & $\begin{array}{l}0.0883 \\
(0.0614)\end{array}$ & $\begin{array}{l}0.0827 \\
(0.0617)\end{array}$ & $\begin{array}{l}0.0429 \\
(0.0643)\end{array}$ & $\begin{array}{l}0.0769 \\
(0.0758)\end{array}$ & $\begin{array}{l}0.0754 \\
(0.0758)\end{array}$ \\
\hline $\begin{array}{l}\text { Level in the } \\
\text { society (SOCLEV) }\end{array}$ & $\begin{array}{l}0.2549 \\
(0.3948)\end{array}$ & $\begin{array}{l}0.8589 * * \\
(0.3649)\end{array}$ & $\begin{array}{l}0.9534 \\
(0.3984)\end{array}$ & $\begin{array}{l}0.0875 \\
(0.4476)\end{array}$ & $\begin{array}{l}0.6394 \\
(0.3971)\end{array}$ & $\begin{array}{l}0.7100 \\
(0.4391)\end{array}$ \\
\hline Constant & $\begin{array}{l}1.4575 \\
(3.3588)\end{array}$ & $\begin{array}{l}-3.8308 \\
(2.9647)\end{array}$ & $\begin{array}{l}-2.3279 \\
(3.2061)\end{array}$ & $\begin{array}{l}2.0340 \\
(4.0123)\end{array}$ & $\begin{array}{l}-2.9024 \\
(3.6389)\end{array}$ & $\begin{array}{l}-1.6229 \\
(3.8978)\end{array}$ \\
\hline R-sq & 0.7948 & 0.7200 & 0.7357 & 0.6578 & 0.5859 & 0.5947 \\
\hline Number of observation & 27 & 27 & 27 & 27 & 27 & 27 \\
\hline
\end{tabular}

Robust standard errors in parentheses

$* p<0.10 ; * * p<0.05 ; * * * p<0.01$

$$
\hat{\beta}=\frac{\operatorname{Cov}(x, y)-\gamma \mathrm{V}(\mathrm{y})}{\mathrm{V}(\mathrm{x})-\gamma \operatorname{Cov}(\mathrm{x}, \mathrm{y})}
$$

when $\gamma=0 \hat{\beta}=\operatorname{COV}(\mathrm{x}, \mathrm{y}) / \mathrm{V}(\mathrm{x})$ which corresponds to the OLS estimator of CEB present in Table 4 which assumes that there is no effects of confidence on corruption, i.e. no reverse causation. On the contrary, $\hat{\beta}=0$ when $\gamma=\operatorname{COV}(\mathrm{x}, \mathrm{y}) / \mathrm{V}(\mathrm{y})$ which represents the OLS estimator of the reverse effect of confidence on corruption, in case of absence of impact of corruption on confidence. Following Clausen et al. (2011) we use the range of values comprised between $\gamma=0$ and $\gamma=\operatorname{COV}(\mathrm{x}, \mathrm{y}) / \mathrm{V}(\mathrm{y})$ to compute the magnitude of the potential reverse causation. Assuming that $\gamma>0$, that means that more confidence implies more corruption control, we compute the value of $\hat{\beta}$ conditional to a set of values of $\gamma<\operatorname{COV}(\mathrm{x}, \mathrm{y}) / \mathrm{V}(\mathrm{y})$, level at which would mean that $\beta<0$ implying that less corruption control raises confidence, which seems implausible.

Figure 4 shows two graphs that plot the estimate of $\beta$ (conditional to $\gamma$ ) on the vertical axis and the different values of $\gamma$ on the horizontal axis. ${ }^{15}$ The top graph presents the relationship between CEB and CONFPARL, while the bottom one has CONFGOV as dependent variable. In both graphs we can easily note that when $\gamma=0$ we have the OLS

${ }^{15}$ We are very grateful to Aart Kraay that sent us the excel do-file to plot the graphs reported in Fig. 4. 
Estimation of the impact of Corruption perceptions (CEB) on confidence in parliament (CONFPARL)

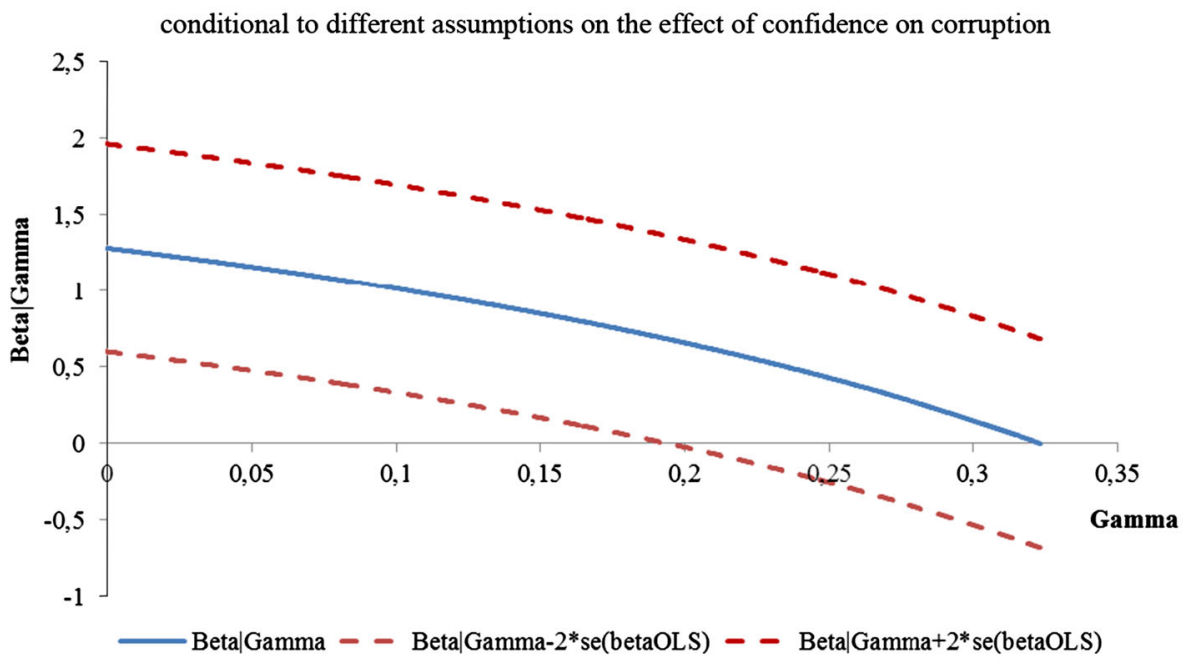

Estimation of the impact of Corruption perceptions (CEB) on confidence in government (CONFGOV) conditional to different assumptions on the effect of confidence on corruption

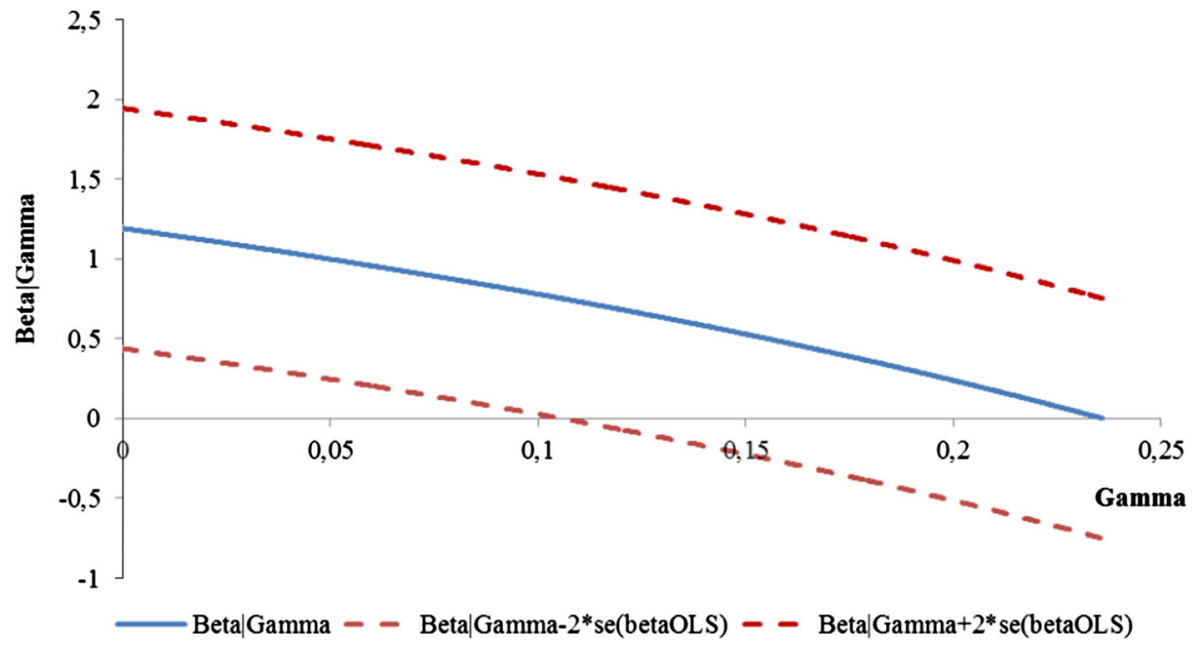

Fig. 4 Robustness Checks of Empirical Results to Reciprocal Causality

estimate of $\beta$ reported in Model 7 and 10 of Table 4. With increasing values of $\gamma$, which means a higher impact of confidence on corruption, the value of $\beta$ becomes closer to 0 . The reported $95 \%$ confidence interval of $\beta$ indicate that the estimate of $\beta$ becomes insignificantly different from 0 only for quite large values of $\gamma(\gamma=0.2$ in the top plot and $\gamma=0.1$ in the bottom plot).

From this analysis we can conclude that it seems very plausible that there is a bidirectional causality between corruption and confidence. However, even though 
institutional confidence have an impact on corruption, this should be quite strong in order to undermine the significant effect of corruption on confidence.

\section{Conclusions}

This study has investigated the effects of different perceptions-based indexes of corruption on institutional confidence among EU member states. In line with previous studies conducted in Western consolidated democracies (della Porta 2000; Anderson and Tverdova 2003), post-communist regimes of Eastern Europe (Mishler and Rose 2001), Asian (Chang and Chu 2006), African (Cho and Kirwin 2007) and Latin American countries (Seligson 2002), our main results confirm that corruption negatively affects citizens' confidence in political institutions also in EU member states.

In a period in which international economic and financial crisis is challenging the already tenuous relationship between rulers and ruled political corruption maintains a significant negative impact on the confidence that EU citizens put in two key institutions of contemporary representative democracies, the government and the parliament. The most important contribution of this study consists in demonstrating that this relationship holds irrespective of whether we measure corruption with the most commonly used indexes gathered from experts' surveys (CPI and CC) or aggregating the individual perceptions of the general public in a newly developed index named CEB.

This study illustrates, through a detailed exploratory analysis, that mass perceptionsbased indexes are reliable indicators of corruption. In fact, at least in EU member states, common citizens' and experts' perceptions tend to move together. This means that the evaluations of the economic elite and the international private sector are not disconnected from the sentiments of the citizens. At the same time, this demonstrates that citizens' perceptions are not necessarily avulsed from the reality. This is true even though in some countries common citizens' perceptions are quite different from the experts' evaluations. However, an in-depth comparison of these different types of indexes have shown us that we cannot identify a clear tendency according to which citizens' perceptions differentiate from the experts' ones. There are instead two contrasting tendencies in act. While in some countries (Cyprus, Ireland and Portugal) citizens tend to over-estimate the level of corruption as perceived by the experts, in other countries (Estonia, Poland, Slovakia and Italy) the tendency is exactly the opposite. Cultural norms and traditions present in particular in Southern and Eastern European countries induce citizens to be more permissive toward corruption than in Scandinavian and North-Continental Europe.

In conclusion, these differences do not necessarily invalidate the use of mass' perceptions-based indexes in cross-country comparative analyses. Future studies on the consequences of corruption would highly benefit from the triangulation of different perceptions-based and experience-based indexes, even though more scholarly attention should be devoted to explain which factors drive both experts' and mass' perceptions of corruption.

\section{Appendix}

See Table 5 . 
Table 5 Labels of the variables' modalities which appear in Fig. 1

\begin{tabular}{|c|c|}
\hline Name of the modality & Label \\
\hline no_corr_totally_agree & $\begin{array}{l}\text { Respondents who totally disagree that corruption is a major problem in their } \\
\text { country }\end{array}$ \\
\hline no_corr_regional inst. & $\begin{array}{l}\text { Respondents who tend to partially disagree/totally disagree that there is } \\
\text { corruption in regional institutions }\end{array}$ \\
\hline no_corr_local_inst. & $\begin{array}{l}\text { Respondents who tend to partially disagree/totally disagree that there is } \\
\text { corruption in local institutions }\end{array}$ \\
\hline no_corr_partially_agree & $\begin{array}{l}\text { Respondents who partially disagree that corruption is a major problem in own } \\
\text { country }\end{array}$ \\
\hline gov_effectiveness & $\begin{array}{l}\text { Respondents who tend to agree/totally agree that governments effort to } \\
\text { combat corruption are effective }\end{array}$ \\
\hline manager & Manager is the last Respondents' occupation \\
\hline no_corr_pol_nat & $\begin{array}{l}\text { Respondents who do not think that corruption (giving and taking of bribes, } \\
\text { and the abuse of positions of power for personal gain) is widespread among } \\
\text { politicians at national level }\end{array}$ \\
\hline no_corr_pol_reg & $\begin{array}{l}\text { Respondents who do not think that corruption (giving and taking of bribes, } \\
\text { and the abuse of positions of power for personal gain) is widespread among } \\
\text { politicians at regional level }\end{array}$ \\
\hline no_corr_pol_loc & $\begin{array}{l}\text { Respondents who do not think that corruption (giving and taking of bribes, } \\
\text { and the abuse of positions of power for personal gain) is widespread among } \\
\text { politicians at local level }\end{array}$ \\
\hline no_corr_health_sec & $\begin{array}{l}\text { Respondents who do not think that corruption (giving and taking of bribes, } \\
\text { and the abuse of positions of power for personal gain) is widespread among } \\
\text { people working in the public health sector }\end{array}$ \\
\hline no_corr_pub_educ & $\begin{array}{l}\text { Respondents who do not think that corruption (giving and taking of bribes, } \\
\text { and the abuse of positions of power for personal gain) is widespread among } \\
\text { people working in the public education sector }\end{array}$ \\
\hline no_corr_custom_ser & $\begin{array}{l}\text { Respondents who do not think that the corruption (giving and taking of bribes, } \\
\text { and the abuse of positions of power for personal gain) is widespread among } \\
\text { people working in the customs service }\end{array}$ \\
\hline no_corr_bussiness_officials & $\begin{array}{l}\text { Respondents who do not think that corruption (giving and taking of bribes, } \\
\text { and the abuse of positions of power for personal gain) is widespread among } \\
\text { officials issuing business permits }\end{array}$ \\
\hline Europe_responsability & $\begin{array}{l}\text { Respondents who think that preventing and fighting corruption is the } \\
\text { responsibility of the European Union institutions }\end{array}$ \\
\hline corr_bussiness_officials & $\begin{array}{l}\text { Respondents who think that corruption (giving and taking of bribes, and the } \\
\text { abuse of positions of power for personal gain) is widespread among officials } \\
\text { issuing business permits }\end{array}$ \\
\hline corr_custom_serv & $\begin{array}{l}\text { Respondents who think that corruption (giving and taking of bribes, and the } \\
\text { abuse of positions of power for personal gain) is widespread among people } \\
\text { working in the customs service }\end{array}$ \\
\hline judicial sys_figth_corr & $\begin{array}{l}\text { Respondents who think that preventing and fighting corruption is the } \\
\text { responsibility of the judicial system (prosecution services and courts) }\end{array}$ \\
\hline corr_health_sec & $\begin{array}{l}\text { Respondents who think that corruption (giving and taking of bribes, and the } \\
\text { abuse of positions of power for personal gain) is widespread among people } \\
\text { working in the public health sector }\end{array}$ \\
\hline corr_pol_loc & $\begin{array}{l}\text { Respondents who think that corruption (giving and taking of bribes, and the } \\
\text { abuse of positions of power for personal gain) is widespread among } \\
\text { politicians at local level }\end{array}$ \\
\hline corr_pol_reg & $\begin{array}{l}\text { Respondents who think that corruption (giving and taking of bribes, and the } \\
\text { abuse of positions of power for personal gain) is widespread among } \\
\text { politicians at regional level }\end{array}$ \\
\hline
\end{tabular}


Table 5 continued

\begin{tabular}{ll}
\hline Name of the modality & Label \\
\hline corr_police & $\begin{array}{c}\text { Respondents who think that corruption (giving and taking of bribes, and the } \\
\text { abuse of positions of power for personal gain) is widespread among police } \\
\text { service } \\
\text { Respondents who think that corruption (giving and taking of bribes, and the } \\
\text { abuse of positions of power for personal gain) is widespread among } \\
\text { politicians at national level } \\
\text { corr_pol_nat } \\
\begin{array}{l}\text { Respondents who has an high education level } \\
\text { Respondents who tend to fairly agree/totally agree that there is corruption in } \\
\text { national institutions }\end{array} \\
\text { Respondents who tend to fairly agree/totally agree that there is corruption in } \\
\text { regional institutions } \\
\text { Respondents who tend to fairly agree/totally agree that there is corruption in } \\
\text { local institutions }\end{array}$ \\
\hline
\end{tabular}

\section{References}

Adbi, H., \& Valentine, D. (2007). Multiple correspondence analysis. In N. Salkind (Ed.), Encyclopedia of measurement and statistics (pp. 651-657). Thousand Oaks, CA: Sage.

Anderson, C. J., \& Tverdova, Y. V. (2003). Corruption, political allegiances and attitudes toward government in contemporary democracies. American Journal of Political Science, 47(1), 91-109.

Andersson, S., \& Heywood, P. M. (2009). The politics of perception: Use and abuse of Transparency International's approach to measuring corruption. Political Studies, 57(4), 746-767.

Banducci, S. A., Karp, J. A., \& Loedel, P. H. (2003). The Euro, economic interests and multilevel governance: Examining support for the common currency. European Journal of Political Research, 42(5), $685-703$.

Banducci, S. A., Karp, J. A., \& Loedel, P. H. (2009). Economic interests and public support for the Euro. Journal of European Public Policy, 16(4), 564-581.

Chang, E. C. C., \& Chu, Y. (2006). Corruption and trust: Exceptionalism in Asian democracies? Journal of Politics, 68(2), 259-271.

Cho, W., \& Kirwin, M. F. (2007). A vicious cycle of corruption and mistrust in institutions in Sub-Saharan Africa: A micro-level analysis. Afrobarometer Working Papers, No. 71. Michigan State University, East Lansing, MI.

Clausen, B., Kraay, A., \& Nyiri, Z. (2011). Corruption and confidence in public institutions: Evidence from a global survey. The World Bank Economic Review, 25(2), 212-249.

Criado, H., \& Herreros, F. (2007). Political support. Taking into account the institutional context. Comparative Political Studies, 40(12), 1511-1532.

della Porta, D. (2000). Social capital, beliefs in government, and political corruption. In S. Pharr \& R. Putnam (Eds.), Disaffected democracies: What's troubling the trilateral countries (pp. 208-228). Princeton, NJ: Princeton University Press.

Donchev, D., \& Ujhelyi, G. (2007). Do corruption indices measure corruption? Unpublished paper, Harvard University, MA.

Döring, H., \& Manow, P. (2011). Parliament and government composition database (ParlGov): An infrastructure for empirical information on parties, elections and governments in modern democracies. Version 11/07-26 July 2011. http://www.parlgov.org/

Easton, D. (1965). A system analysis of political life. New York, NY: Wiley.

Easton, D. (1975). A re-assessments of the concept of political support. British Journal of Political Science, 5(4), 435-457.

Greenacre, M. \& Pardo, R. (2005). Multiple correspondence analysis of a subset of response categories. SSRN working paper. http://ssrn.com/abstract $=847647$

Hobolt, S. B., \& Leblond, P. (2009). Is my crown better than your euro? Exchange rates and public opinion on the European single currency. European Union Politics, 10(2), 202-225. 
Horowitz, S., Hoff, K., \& Milanovic, B. (2009). Government turnover: Concepts, measures and applications. European Journal of Political Research, 48(1), 107-129.

Kaufmann, D., Kraay, A., \& Zoido-Lobaton, P. (1999). Governance matters. World Bank policy research working paper n. 2196. The World Bank, Washington DC.

Kaufmann, D., \& Wei, S. (1999). Does 'grease money' speed up the wheels of commerce? NBER working paper no. 7093. National Bureau of Economic Research, Cambridge, MA.

Ko, K., \& Samajdar, A. (2010). Evaluation of international corruption indexes: Should we believe them or not? The Social Science Journal, 47(3), 508-540.

Lancaster, T. D., \& Montinola, G. R. (1997). Toward a methodology for the comparative study of political corruption. Crime, Law \& Social Change, 27(1), 185-206.

Lancaster, T. D., \& Montinola, G. R. (2000). Comparative political corruption: Issues of operationalization and measurement. Studies in Comparative Institutional Development, 36(3), 3-28.

Le Roux, H., \& Rouanet, B. (2004). Geometric data analysis. From correspondence analysis to structured data. Amsterdam: Kluwer.

Leamer, E. (1981). Is it a supply curve or is it a demand curve? Partial identification through inequality constraints. Review of Economics and Statistics, 63(3), 319-327.

Lijphart, A. (1999). Patterns of democracies: Government forms and performance in thirty-six democracies. New Heaven, CT: Yale University Press.

Linz, J. J., \& Stepan, A. (1996). Problems of democratic transition and consolidation. Southern Europe, South America and Post-communist Europe. Baltimora, MD: The John Hopkins University Press.

Lipset, S. M., \& Lenz, G. B. (2000). Corruption, culture and markets. In L. E. Harrison \& S. P. Huntington (Eds.), Culture matters. How values shape human progress (pp. 112-124). New York, NY: Basic Books.

Mauro, P. (1995). Corruption and growth. Quarterly Journal of Economics, 110(3), 681-712.

Mishler, W., \& Rose, R. (2001). What are the origins of political trust? Testing institutional and cultural theories in post-communist societies. Comparative Political Studies, 34(1), 30-62.

Mishler, W., \& Rose, R. (2008). Seeing is not always believing: Measuring corruption perceptions and experiences. Unpublished paper, University of Manchester, UK.

Pellegata, A. (2013). Constraining political corruption: An empirical analysis of the impact of democracy. Democratization, 20(7), 1195-1218.

Powell, G. B. (2000). Elections as instruments of democracy: Majoritarian and proportional visions. New Haven, CT: Yale University Press.

Roberts, A. (2006). What kind of democracy is emerging in Eastern Europe? Post-Soviet Affairs, 22(1), 37-64.

Rose-Ackerman, S. (1999). Corruption and government. Causes, consequences and reforms. Cambridge: Cambridge University Press.

Sandholtz, W., \& Taagepera, R. (2005). Corruption, culture and communism. International Review of Sociology, 15(1), 109-131.

Seligson, M. A. (2002). The impact of corruption on regime legitimacy: A comparative study of four Latin American countries. Journal of Politics, 64(2), 408-433.

Siaroff, A. (2003). Corporatism in 24 industrial democracies: Meaning and measurement. European Journal of Political Research, 36(2), 175-205.

Sovey, A. J., \& Green, D. P. (2011). Instrumental variables estimation in political science: A reader's guide. American Journal of Political Science, 55(1), 188-200.

Treisman, D. (2000). The causes of corruption: A cross-national study. Journal of Public Economics, 76(3), $399-458$.

Treisman, D. (2007). What we have learned about the causes of corruption from ten years of cross-national empirical research? Annual Review of Political Science, 10, 211-244.

Uslaner, E. M. (2004). Trust and corruption. In J. G. Lambsdorff, M. Taube, \& M. Schramm (Eds.), The new institutional economics of corruption (pp. 76-92). London: Routledge.

Wagner, A., Schneider, F., \& Halla, M. (2009). The quality of institutions and satisfaction with democracy in Western Europe-A panel analysis. European Journal of Political Economy, 25(1), 30-41.

Wallace, C., \& Latcheva, R. (2006). Economic transformation outside the law: Corruption, trust in public institutions and the informal economy in transition countries of Central and Eastern Europe. EuropeAsia Studies, 58(1), 81-102.

Warren, M. E. (2004). What does corruption mean in a democracy? American Journal of Political Science, $48(2), 328-343$. 